\title{
THE NEW GOVERNMENT ARMAMENTS PROGRAM IS TAKING SHAPE \\ V.Zatsepin
}

After the July and September meetings of the Military-Industrial Commission of the Russian Federation, the RF Government continued its search for a compromise concerning the ceiling for budget funding to be allocated to the next government armaments program for 2018-2025; however, the target suggested by the financial-economic bloc had already been planned in the draft federal budget for the period 2017-2019. The new armaments program must be submitted for the RF President's approval by July 1, 2017.

In June 2016, the Military-Industrial Commission of the Russian Federation (RF MIC), a year and a half after its first attempt to do so, once again sat down to discuss the financial and economic parameters of the new government armaments program for $2018-2025^{1}$. As can be judged by the information leaks to news media concerning the classified part of that meeting, the government's financial department agreed to allocate no more than $\mathrm{Rb} 12$ trillion to that program, while the military demanded more than $\mathrm{Rb} 24$ trillion, or twice as much², for 'guaranteed national security'. In other words, no compromise could be achieved in June.

The search for a compromise was continued in September when, during the meeting with the RF President, Russia's Deputy Prime Minister delivered a report on the comprehensive assessment of RF budget expenditure to be allocated to the next government armaments program (GAP) ${ }^{3}$. However, after the report was over, 'the discussion degenerated into a row' due to the continuing disagreement concerning the ceiling for budget allocation: RF Minister of Finance Andrey Siluanov persisted in supporting the ceiling set at Rb 12 trillion, while RF Minister of Defense Sergey Shoigu, this time, spoke of a total of 'approximately Rb 22 trillion.' ${ }^{4}$ In other words, since December 2014, when the RF Ministry of Defense had first voiced its claims to a budget of $\mathrm{Rb} 30$ trillion to be allocated to its (then) 10-year program, the amount of planned funding was cut by $\mathrm{Rb} 8$ trillion in absolute terms; and due to the planning horizon having been shortened by 2 years, from $\mathrm{Rb} 3$ trillion to $\mathrm{Rb} 2.75$ trillion in per annum terms. Given the crisis conditions of Russia's economy over the past two years coupled with the absence of any hopes for its sustainable growth in the nearest future, ${ }^{5}$ the RF Ministry of Defense's

1 Meeting of the Military-Industrial Commission of the Russian Federation. Moscow, the Kremlin, June 28, 2016. See http://www.kremlin.ru/events/president/news/52288 (reference date: October 27, 2016).

2 Safronov I., Sapozhkov O. The battle for the budget. Kommersant, 2016, July 4 (Issue 117). See http://www.kommersant.ru/doc/3029601 (reference date: October 27, 2016).

3 Meeting on the main parameters of the government armaments program for 2018-2025. Moscow Oblast, Novo-Ogarevo, September 9, 2016. See http://www.kremlin.ru/events/president/news/52866 (reference date: October 27, 2016).

4 Safronov I. If not toe-in, then toe-out. Kommersant, 2016, September 17 (Issue 172). See http://kommersant.ru/doc/3092628 (reference date: October 27, 2016).

5 Netreba P. The stagnation will last 20 years. Gazeta.ru, 2016, October 20. See https:// www.gazeta.ru/business/2016/10/19/10259831.shtml (reference date: October 27, 2016). 
position in these negotiations is pretty weak, and so, in the course of several interdepartmental meetings planned to take place until the end of this year, the RF MIC is very likely to agree to a compromise on the terms suggested by the RF Ministry of Finance, which have already been stipulated in the draft federal budget for 2017-2019 prepared by the RF Government for the discussion and approval by the State Duma (Rb 1.5 trillion per annum) ${ }^{1}$.

In principle, keeping the budget funding at that level until the end of the program implementation period will make it possible to avoid any significant cuts on the government defense order (GDO) in nominal terms after 2020 (the threat that Russia's leaders have recently repeatedly warned of the CEOs of the Russian defense-industrial complex (DIC)). Naturally, once this threat is removed, it will become easier to deal with the task of diversifying the defense industry and increasing the output of civil-use and dual-use products by the enterprises belonging to the DIC ${ }^{2}$.

Besides, the standpoint of the RF Ministry of Defense in its struggle for funding in the framework of the GAP appears to be weak, for subjective reasons.

Firstly, the government already knows the true cost of the current GAP, which is 1.5 times higher than the initial budget ceiling set by the RF Ministry of Finance. Meanwhile, it has transformed into a 'strategic long-term forecast that is no longer valid', while the government program itself 'further and further deviates from the year-on-year government defense order parameters in terms of nomenclature, price, etc.' ${ }^{3}$

Secondly, complaints of the GAP's authors about the lack of properly detailed and accurate data needed for estimating the necessary amount of funding ${ }^{4}$ can no longer be taken seriously after the RF Ministry of Defense, in December 2014, rather unashamedly announced that it had reduced its own estimates of the value of the new GAP from $\mathrm{Rb} 55$ trillion to $\mathrm{Rb} 30$ trillion $\mathrm{Rb}$, which was possible due to nomenclature unification ${ }^{5}$. The Ministry obviously forgot that a version that had not been subject to unification could not, for obvious reasons, be regarded as an armaments program. It has already been noted elsewhere ${ }^{6}$ that it is the uncontrolled expansion of the armaments and military technology nomenclature coupled with lack of their proper unification that was one of the main reasons for the switchover to long-term planning in the armaments development sphere, introduced 47 years ago in

1 Butrin D., Skorobogatko D., Visloguzov V. The peacetime budget. Kommersant, 2016, October 27 (Issue 200). See http://kommersant.ru/doc/3126798 (reference date: October 27, 2016).

2 Meeting on the uses of the defense-industrial complex's potential in manufacturing hitech products for civil use. Tula, September 8,2016 . See http://www.kremlin.ru/events/president/news/52852 (reference date: October 27, 2016).

3 Report by Deputy Chairperson of the Accounts Chamber of the Russian Federation V. Chistova to the State Duma on July 1, 2015. See http://transcript.duma.gov.ru/node/4314/ (reference date: October 27, 2016).

4 Burenok V. Government disarmament program. Military-Industrial Courier. 2016, August 31 (No 33). See http://vpk-news.ru/articles/32056/ (reference date: October 27, 2016).

5 Kravchenko $A$. By reducing the armaments nomenclature by $36 \%$, we will save $\mathrm{Rb} 30$ trillion. Izvestia, 2014, December 30. See http://izvestia.ru/news/581385/ (reference date: October 27, 2016).

6 The forthcoming government armaments program: new priorities and old problems. Russian Economic Developments, 2014. No 2, p. 55. See http://www.iep.ru/files/text/ RED/2014/Russian_Economic_Developments_02_2014.pdf (reference date: October 27, 2016). 
the USSR by Decree of the CPSU Central Committee and the USSR Council of Ministers, as of June 10, 1969, No 433-157-69, 'On Further Improvement of Planning of the Development of Armaments and Military Technologies'.

Thirdly, the data recently released by the Accounts Chamber of the Russian Federation provide a more accurate picture of the refinancing crisis in the DIC, which became manifest in 2015 in the form of a surge in the amount of receivables against issued advance payments. Thus, for example, as a result of $100 \%$ advance payments made in 2015 by the RF Ministry of Defense in the framework of its contracts, its receivables towards the year's end rose to $\mathrm{Rb} 2$ trillion $405 \mathrm{bn}$ (or $73.4 \%$ of its total debt against advance payments covered by the federal budget). Meanwhile, the budget reports for 2015 submitted by the RF Ministry of Defense failed to reflect its outstanding receivables (the advance payments for work that had not been done) under 267 investment contracts in the amount of Rb $88.2 \mathrm{bn}$. The amount of the RF Ministry of Defense's payables by late 2015 had risen to Rb 598.5bn, of by $22.8 \%$ on the previous year ${ }^{2}$.

This year, as seen by the period-end results of $\mathrm{H} 12016$, the receivables against advance payments issued by the RF Ministry of Defense once again increased by $\mathrm{Rb} 529.6 \mathrm{bn}$, or by $22 \%$, to $\mathrm{Rb} 2$ trillion $935.5 \mathrm{bn}$, which is more than the value of its half-year GDO, while outstanding receivables amounted to $\mathrm{Rb} 253.4 \mathrm{bn}$. Nevertheless, during the federal budget's adjustment by the government in autumn 2016, it was suggested that the contributions to the charter funds of some of the organizations belonging to the DIC that reported high outstanding receivables should be increased (United Shipbuilding Corporation JSC: by Rb $971,9 \mathrm{~m}$, or $21.9 \%$ (its outstanding receivables amounting to Rb 110.8bn); and United Aircraft Corporation PJSC: by Rb 2bn 245.6m, or $82.4 \%$ (its outstanding receivables amounting to $\mathrm{Rb} 84.6 \mathrm{bn}$ ) 3 .

Therefore it is quite natural that, in the course of the Single Day for the Approval of Military Products on October 21, RF Minister of Defense Sergey Shoigu reported that approximately $2.5 \%$ of enterprises had failed to fulfill their GDO, and further specified that for a number of them, 'the decision was made that the contracts with them should be terminated, the money refunded, and new contracts promptly concluded with other enterprises concerning the same product nomenclature ${ }^{\prime 4}$.

However, it is easier to announce that 'we will deal most severely with such "delivery schedule failures' and 'incomplete works's than to actually do so. As demonstrated by the results of recent financial management quality monitoring by the chief federal budget allocation administrators, the RF

1 Patrushev N. The strong are not attacked. Military-Industrial Courier, 2013, March 27 (No. 12). See http://vpk-news.ru/articles/15103 (reference date: October 27, 2016).

2 The Accounts Chamber of the Russian Federation's resolution concerning the report on federal budget execution in 2015. No. 3CП - 166/16-09 of August 31, 2016. See http://asozd2. duma.gov.ru/main.nsf/(ViewDoc)?OpenAgent\&work/dz.nsf/ByID\&B425EDD8066C9C994325 804500496D97 (reference date: October 27, 2016).

3 Resolution of the Accounts Chamber of the Russian Federation concerning draft Federal Law No. 2428-7 'On Introducing Alterations into Federal Law "On the Federal Budget for 2016". No. 3SP-178/16-09 of October 14, 2016. See http://asozd2.duma.gov.ru/main.nsf/ (ViewDoc)?OpenAgent\&work/dz.nsf/ByID\&5035346B7E07756F4325804F003B453C (reference date: October 27, 2016).

4 The RF Minister of Defense, General of the Army Sergey Shoygu conducts the Single Day for the Approval of Military Products. October 21, 2016. URL: http://function.mil.ru/news page/country/more.htm?id=12100458@egNews (reference date: October 27, 2016).

5 Ibid. 
Ministry of Defense ranked 84th among 95 government departments, with the worst personnel, reporting and accounting indices ${ }^{1}$.

In accordance with the September assignment of the RF President, the proposals concerning the new GAP should be pooled into a single document by late 2016 , and its draft be submitted for approval by July $1,2017^{2}$.

1 Report on the results of financial management quality monitoring by the chief federal budget allocation administrators as of July 1, 2016. M.: RF Ministry of Finance, 2016. See http://minfin.ru/common/upload/library/2016/09/main/2016.07.01_MKFM.xls (reference date: October 27, 2016).

2 Pogozin: The Collegium of the Military-Industrial Commission of the Russian Federation set out to develop the new government armaments program. TASS, 2016, September 9. See http://tass.ru/armiya-i-opk/3609918 (reference date: October 27, 2016). 